\title{
National Symbols as Commemorative Emblems in Nigerian Films
}

\author{
Alawode, Sunday Olayinka PhD \\ Adesanya, Oluseyi Olufunke \\ Agboola, Olufunsho Cole \\ Lagos State University School Of Communication \\ Lagos, Osodi, Lagos State, Nigeria \\ Religion, Communication and Culture Working Group
}

Doi: 10.19044/esj.2018.v14n2p100 URL:http://dx.doi.org/10.19044/esj.2018.v14n2p100

\begin{abstract}
Nigerian films worldwide are the entertainment offerings of the nation, a burgeoning industry with steady increase growth rate and contributing substantially to the GDP of the nation. National symbols are objects, entities and relics representing an idea, concept, character that may be physical, abstract, religious, cultural, and linguistic among others in a sovereign context and beyond. Symbols or objects that connected together may not have anything in common in reality but by association and common agreement, they have come to represent each other in social contexts; a symbol may arbitrarily denote a referent, icon and index. In the case of Nigeria, the National flag, Anthem, Pledge, Currency, language, Coat of arms, National institutions like the National Assembly complex, Federal Capital Territory (FCT), images of past leaders, historical monuments like the Unknown Soldier (representing military men who died in the cause of protecting the nation), dresses are some of these national symbols. Apart from commemorative historical functions, national symbols are also used to represent hard work, credibility or truthfulness, as well as ethnic differentiation, religious affiliation, cultural background, social status, professional orientation, class distinction among others. Theorizing with Gate-keeping and Framing Analysis, this study adopts a content analysis design which is the study of recorded human communications, an objective and systematic analysis of the contents of any document that are manifest. It is often used to investigate the level of presence of a given content in mass communication. The study selected thirty video films between 2010 and 2015 through a systematic sampling with a random start. Content categories include genre of film, type of symbol, setting of symbol, purpose of symbol, cultural implication of symbol, positioning of symbol, symbiotic relations, prominence, and direction of presentation among
\end{abstract}


others. The study presumed that the nation is replete with communicative, symbolic emblems commemorating historical, cultural, religious, social and family landmarks in nationhood but that these items of symbols are minimally represented in the films that stand as cultural products and identity of the nation in the international community. Findings of the study have dire implications for the critical assessment, representation and image or identity of the nation for the past, present and the future.

Keywords: National symbols, Commemorative emblems, Nigerian films, Content analysis

\section{Introduction}

National symbol is an artistic, natural, or human representation of a nation's identity (Redmond WA, 2008). National symbols intend to unite people by creating visual, verbal, or iconic representations of the national peoples, values, goals or history. These symbols are often rallied around as part of celebrations of patriotism or aspiring nationalism (such as independence, autonomy or separation movements) and are designed to be inclusive and representative of all the people of the national community. National symbols often do not only represent the general concept 'nation,' but also condense the knowledge, values, history, and memories associated with one's nation (Butz, 2009). He also notes that exposure to the national symbols of one's country can impact people's attitudes and actions, as national symbols hold the potential to represent the strong emotional attachments felt for one's nation.

Tanis, Nicholas (2008) defines film as a series of images that are projected onto a screen to create the illusion of motion. Film is one of the most popular forms of entertainment, enabling people to immerse themselves in an imaginary world for a short period of time. Films also teach people about history, science, human behavior, and many other phenomena. Film is considered to be an important art form, a source of popular entertainment, and a powerful medium for educating or indoctrinating citizens.

Despite the importance of national symbols to nationhood and the power of films in indoctrinating the masses, the study presumed that the nation Nigeria is replete with communicative, symbolic emblems commemorating historical, cultural, religious, social and family landmarks in nationhood. However, these items of symbols are minimally represented in Nigerian films that stand as cultural products and identity of the nation in the international community.

The study therefore aims at assessing the extent in which Nigeria national symbols are represented in Nigerian films, ascertaining lights in which Nigeria national symbols were being represented in Nigerian films and 
ascertaining the identity/image of the nation, Nigeria being projected through the national symbols utilised in Nigeria films project.

\section{Research Questions}

- $\quad$ To what extent are Nigeria national symbols represented in Nigerian films?

- In what light are utilized national symbols projected in Nigerian films?

- What identity/image of Nigeria do national symbols in films portray?

\section{The Nation Nigeria}

Nigeria, a country with an estimated population of $126,635,626$ is the largest black nation in the world. The Federal Republic of Nigeria, as it is officially known, covers an area of 356,669 square miles on the coast of West Africa. Its borders are contiguous with the Federal Republic of Cameroon to the east, Niger Republic to the north and Benin Republic to the east. In the northeast, Nigeria has a 54-mile long border with the Republic of Chad, while its Gulf of Guinea coastline stretches for more than 500 miles from Badagry in the west to Calabar in the east, and includes the Bights of Benin and Biafra. Today, Nigeria is divided administratively into thirty-six states and the Federal Capital Territory of Abuja (CIA World Factbook, 2001).

Like Africa as a whole, Nigeria is physically, ethnically, and culturally diverse. This is partly due to the fact that Nigeria is today inhabited by a large number of tribal groups. According to the Encyclopædia Britannica, an estimated 250 of them speaking over four hundred languages, many with dialects. Muslims and Christians comprise more than 80 percent of the population while the rest are identified with indigenous religions.

\section{National Symbols}

National symbols intend to unite people by creating visual, verbal, or iconic representations of the national peoples, values, goals or history. These symbols are often rallied around as part of celebrations of patriotism or aspiring nationalism (such as independence, autonomy or separation movements) and are designed to be inclusive and representative of all the people of the national community.

The Nigeria national symbols represent the varied customary beliefs of the country that has been a part of its rich heritage since many years. With a population of more than 120 million, the country, Nigeria stands tall as one of the fastest growing economies of the world. An analysis of the background of the national symbols of Nigeria gives us a clear idea of the various aspects of Nigerian life.

\section{The Following is the List of Some of the Nigeria National Symbols}


- $\quad$ The Nigeria National Flag

- The Nigeria National Coat of Arms

- The Nigeria National Anthem

- $\quad$ The Nigeria National Currency

- Seal of the Nigeria President

\section{The Nigeria National Flag}

The Nigerian National Flag was chosen in 1959 from among 2870 suggestions in a competition; it was designed by a student from Ibadan, Michael Taiwo Akinkunmi. His ensign of the national flag was adjudged as the best among the other entries for prestigious National Flag Design Competition held at the university campus. The then Nigeria High Commissioner to the United Kingdom, M.A. Martins like this ensign and passed a proposal to adopt this design as the Nigeria national flag (flagfoundation.org.ng). Although the flag was adopted in 1959, it did not become the official flag until Nigeria attained independence on 01 October 1960.

The Nigerian National Flag is governed by the Flag and Coat-of-Arms Ordinance of 1960. According to the law, while hoisting the National Flag it should be ceremoniously flown in the morning during sunrise and lowered at sunset as according to them, a flag of national importance does not sleep. It is also important to note that the national flag of Nigeria should be hung or half flown on days of state funerals or important memorial days. If in any case, the flag is in a room, then no other flag should be placed higher than it. If the flag is torn out, it shouldn't be flown or used but rather burned or destroyed.

The law makes it an offence for the National Flag to be improperly used or displayed. Section 5 of the Law states; "any person who flies or exhibits the National Flag in a defaced or bad condition shall be guilty of an offence against this Ordinance."

The importance of national flag of Nigeria lies in the fact that each color represents the rich cultural heritage of the country. As the green color represents the fertile land and agricultural diversity of the land while the white stands for peace and unity at the same time representative of the River Niger that passes through the whole country and is invariably a part of its geographical identity. Thus, the national flag of Nigeria truly reflects the Nigerian nationalistic fervor and sentiments.

\section{The Nigeria National Coat of Arms}

The Nigeria Coat-of-Arms is the country's symbol of national unity, state power and authority. It was created in line with the national Flag and Coat-of-Arms ordinance number 48 of 1960.The Nigeria Coat-of-Arms was adopted officially in 1975. Before this time, each of the country's constituent 
political units had its own Coat-of-Arms.http://nigerianfinder.com/nigeriacoat-of-arm-arms-nigerian-coat-of-arms/

The Nigeria Coat-of-Arms has seven permanent features, each symbolizing a particular entity or virtue about the country;

- $\quad$ A black shield

- $\quad$ Two white wavy bands on the shield, which form the letter ' $Y$ ',

- $\quad$ Two horses on either side of the shield

- $\quad$ Some flowers at the base

- $\quad$ An Eagle standing on the shield

- $\quad$ The wreath (with green and white bands) upon which the horses stand

- $\quad$ The nation's motto on the band around the base of the shield.

The black shield represents the fertile soil of Nigeria. The white wavy bands that form a letter ' $Y$ ' represent the country's main inland waterways, the river Niger and Benue which both meet to form a confluence at Lokoja). The two horses at either side of the shield represent the dignity and pride of Nigeria while the green and white wreath on which the Eagle stands represents the rich agricultural potential of Nigeria. The national motto, 'Unity and Faith, Peace and Progress', is written on the band around the base. This motto was adopted in 1978. Before that time, the country's motto was 'Peace, Unity, and Freedom'.

\section{Display/Usage of the Nigeria National Coat of Arms}

Government presence is depicted in offices and other public places with the placing of the Nigerian Coat-of-Arms side by side with the portrait of the President and Commander-in-Chief. The portrait of the Commander-inChief is usually to the right of the Coat-of-Arms, while that of the Principal Officers/Chief Executives of any government establishment e.g. the Governor or Head of Establishment is on the left of the Coat-of-Arms. This position remains valid when the portraits are hung on the wall.

In a situation where the Head of State, Commander-in-Chief, is addressing the nation the Coat-of-Arms is usually encapsulated in the seal of the nation and placed above the Head of State, Commander-in-Chief's seat. It should be noted that the Commander-in-Chief's portrait as well as that of the Principal Officer of the Government establishment, in which the Coat-ofArms is located, should always support the Coat-of-Arms or the Armorial Bearings.

Note: Improper placement/display or absence of these symbols in offices of Principal Officers/Chief Executives constitutes an offence (Ivan Sachein Bruce Berry, 2015).Online available: http://www.crwflags.com/fotw/flags/ng.html. 


\section{The Nigeria National Anthem and Pledge}

The national anthem of Nigeria begins with words glorifying the country with its rich vibrant culture and heritage. The patriotic fervor finds the best expression through the national anthem because the song takes into account the historical past as well as the aims and aspirations of the future generation. The significance of the national anthem of Nigeria lies in the fact that it binds all Nigerians into one chord even if they reside in far off lands.

Historical facts indicate that the first national anthem of Nigeria was adopted in 1960 and the lyrics were written by Miss Williams, a British national. Later in the subsequent years, in 1978 particularly the then National Publicity Committee of Nigeria organized a competition for a new national song. However, in this contest some winners were picked up for their excellent composition. They were John A Ilechukwu, Eme Etim Akpan, B A Ogunnaike, Sota Omoigui and P. O. Aderibigbe. The music of the present day national anthem of Nigeria was composed by Nigeria Police Band, guided by Ben Odiase. Since Nigeria was a British colony, thus before the achievement of the independence of the country the British national song was sung and performed at popular national festivals and ceremonies.

The Nigeria national anthem and pledge appear as a poem with three stanzas (Gabriel Faniyan, 2013). The first and second stanzas consist of nine lines each while the third, the pledge is composed in six lines. The first stanza's message is directed to the citizens of the country. It is a charge, a call to action to serve the motherland with love and compassionate fervor. It also recalls the past history of the land especially the sacrifice of the national heroes of the country during the struggle for independence of the country. The second stanza also has nine lines. It appears to be a kind of invocation to the Divine, an entreaty to God for help. The pledge occupies the third stanza. It could be taken as a separate whole on its own and it could be a conclusion of the first and second stanzas. In the first and second stanza, Nigeria calls on her citizens and on God respectively. In the third, the Nigerians respond by declaring allegiance to the country beginning with "I" and ending with "God"

\section{The Nigeria National Currency}

The West African Currency Board was responsible for issuing currency notes in Nigeria from 1912 to 1959. Prior to the establishment of the West African Currency Board, Nigeria had used various forms of money including cowries and manilas. Nigeria's unique currency, the Naira symbolized a transition from European influence to one uniquely Nigerian. Online available: http://www.cenbank.org/Currency/historycur.asp

As the official currency of Nigeria, this monetary unit was introduced in 1971, twelve years after independence. The then Head of State announced that Nigeria would change to decimal currency as from 1st January, 1973. The 
major currency unit would be called Naira which would be equivalent to ten shillings: the minor unit would be called kobo; 100 of which would make one Naira. The decision to change to decimal currency followed the recommendations of the Decimal Currency Committee set up in 1962 which submitted its report in 1964. The change that took place in January, 1973 was a major one and this involved both currency notes and coins. The major unit of currency which used to be $£ 1$ ceased to exist and the one Naira which was equivalent to 10/- become the major unit:"Kobo" subdivides the currency unit into 100 equal parts. Naira is depicted with the symbol "W" but due to lack of accessibility of the symbol in most of the fonts, it is often denoted by a simple "N" instead. According to the ISO 4217 regulation, the Nigerian naira is entitled with NGN as the currency code and 566 as the numeric code. Even in plural terms, the currency is known as "naira" only.

\section{Seal of the Nigeria President}

The Seal of the President of the Federal Republic of Nigeria according to (nigerianwiki.com) is the official symbol of the Nigerian President. It was first used in 1979 by President Shehu Shagari in the ill-fated second republic, and jettisoned by the successive military regimes from 1983 - 1999. The presidential seal returned to usage in the wake of the fourth republic in 1999, and it has remained in use till date.

The Seal of the President of Nigeria is based on the Nigerian Coat of Arms. The Coat of Arms of Nigeria has a black shield with two white stripes that come together, like the letter $Y$. These represent the two main rivers flowing through Nigeria: the Benue River and the Niger River. The black shield represents Nigeria's good earth while the two horses on each side represent dignity. The eagle represents strength, while the green and white bands on the top of the shield represent the rich agricultural land of the country. The yellow flower in the grass is the crocus, Nigeria's national flower. The yellow ribbon below has the motto of the Federal Republic of Nigeria, "UNITY AND FAITH, PEACE AND PROGRESS". The words "SEAL OF THE PRESIDENT OF THE FEDERAL REPUBLIC OF NIGERIA" surround the seal in between two concentric green circles.

\section{Modern Usage of the Seal of the President of Nigeria}

The seal is most often seen:

- On official documents from the presidency.

- $\quad$ On the green lectern at presidential press conferences.

- On the sides of presidential transport vehicles (Presidential Air Fleet).

- On the circular rug in the Federal Executive Council chambers in the presidential villa Aso Villa. 


\section{Empirical review}

In a study of expressions of nationhood through national symbols and ceremonies in contemporary Europe, Elgenius (2005) highlights the importance of national symbols and ceremonies in the formation of nations and national identities and examines how they contribute to the expressions of nationhood as integral part of identity- making, maintenance and change. With a focus on contemporary Britain, France and Norway with Germany as analytical counter- case, provided evidence that national symbols and ceremonies express deeper aspects of meanings of the nation, and function as integrative and/ or divisive forces; they form a central part of a 'secular' religion which provides anchorage in a dynamic world; and also have effect upon the community they represent by raising collective consciousness of 'who we are' and 'where we are from' and that adoption of national flag and national day as national symbols are markers denoting arrival of the nation states that evolved in stages that cannot be dated in precise manner. Similarly Bornman (2005) investigated issues of nation-building, national symbols and awareness of distinctive group, membership in post -apartheid South Africa concentrating on symbols like the rainbow nation and new national flag representing enthusiasm that the new political dispensation would usher reconciliation and unity in the diverse South African society. The study reveals that African Blacks identified the strongest with the new national symbols, while non-Blacks especially Afrikaans-speaking Whites-rated them as unimportant. The new constitution recorded high importance from all groups and there were significant differences for pride in being a South African. The study indicates that the role of national symbols might be less important and that of civic elements such as the constitution more important in promoting nationalism. These two studies call attention to national symbols and their importance in national consciousness and identity yet with significant differences based on certain factors like colour while sharing similar worldview for some other symbols like the constitution. In a related dimension, Alawode and Uduakobong (2014) content analysed fifty Nigerian Video films to investigate the portrayals and representations of Nigeria and its people in order to ascertain the reality of Nigerian image through the video film perspectives. The study shows that films effectively reveal Nigerians as religious and traditional people but scanty attention was paid to economic and investment potentials of the nation. The nation's symbols like flags, coat of arms, currencies and so on were scantily portrayed. Negative attitudes of getrich-quick, get-rich-at-all-cost, witchcraft and fetish practices, violence, hooliganism and ritualism among other vices were exaggerated. The video films have misrepresentations, overrepresentations and under- representations of the nation's image. 
Alawode (2005/2006) studied the portrayals of the Nigerian environment in video films through a content analysis and discovers that very little is depicted of the natural environment while homes, markets and religious institutions in urban location had the largest portrayals in the films. The films portrayed locales, places, weather, buildings, moods, sanitation, population, relationships, transactions, occupations and institutions as part of the Nigeria environment; it portrayed Nigerians as triangular beings shuttling between the home, market and religious places; portrayed Nigerians as homely, industrious and religious. Nigeria was portrayed as environment of freedom, orderliness, lawfulness and friendliness. Nigerian environment is usually clean and tidy. The study posits emphatically that Nigerian films did not pay attention to natural environments and national symbols, and as a result were not intended as corporate items for image selling and tourism promotion. In a related study, Alawode (2007) investigated the depiction from the perspective of images captured in entertainment offerings within Nigeria. He found that the Nigerian environment was largely portrayed in terms of filmic and dramatic lines and that very little is reported about the natural environment and national symbols, and therefore calls for deliberately evolved films to promote Nigerian image and locate the Nigerian tourism industry on the global map. Furthermore Alawode and Sunday (2013) analysed the showcasing of Nigeria through portrayals and representations in the home videos and found that film producers extensively project the nation's traditional societies, cultures, beliefs, lifestyles, values, norms, dressings and languages. Religiosity and urbane lifestyles were portrayed with exaggerations of flamboyance, affluence and elegance. The exaggeration extends to portrayal of witchcraft, occultism, and fetishism. They reported that very little is done to showcase the nation's natural resources, agricultural produce, mineral resources, monuments and historical centres, tourist sites as well as national symbols. In a related earlier study, Trevor-Roper (1983) documented 'The Invention of Tradition: The Highland Tradition of Scotland'. Trevor-Roper (2012:15) says:

Whenever Scotchmen gather together to celebrate their national identity, they assert it openly by certain distinctive national apparatus. They wear the kilt, woven in a tartan whose colour and pattern indicate their clan; and if they indulge in music, their instrument is the bag pipe. This apparatus, to which they ascribe great antiquity, is in fact largely modern. It was developed after, sometimes long after, the Union with England against which it is, in a sense, a protest. Before the Union, it indeed existed in vestigial form; but that form was regarded as a by the large majority of Scotchmen as a sign of barbarism: the badge of roguish, idle, predatory, blackmailing Highlanders who were 
more of a nuisance than a threat to civilized, historic Scotland. And even in the Highlands, even in that vestigial form, it was relatively new: it was not original, or the distinguishing badge of the Highland society.

The tradition was never set up to become a tradition in reality, but had its roots in the $14^{\text {th }}$ century, passing through phases, events, wars, parliamentary actions, individual actions, as well as orchestration by the Crown. Apart from earlier developments, it noted the invention of Thomas Rawlison, an English Quaker from Lancashire who invented the Highland dress particularly adapting the original wear to factory wears for his workers. This innovation in 1726 converted the cheap, rocky, mountain wear of the Highlanders into a distinct garment and Rawlinson was the first to wear the garment, followed by his associate, Ian MacDonnel of Glendary, and then his clansmen; the innovation thereafter became handy and convenient that in the shortest space the use became frequent in all the Highland countries among others. The garment almost became extinct by 1780 after it was banned by an act of Parliament as a way to disarm the Highlanders and deprive heir chiefs of their hereditary distinctions with the bagpipe. However, on the expiration of the ban, the garment resurfaced among the upper and middle classes, who had previously despised the servile costume with enthusiasm. Sir Walter Scott and Colonel Stewart also promoted the invention in their work in 1822 while also gaining more publicity through the state visit of King George IV to Edinburgh, being the first Hanoverian monarch to ever appear in the capital of Scotland. This visit promoted clansmen wear among the Highlanders who were invited to pay homage to their king in their differentiated garments, while also creating prospect of a far larger market for garment firms. The TrevorRoper thesis in this work is "that the peculiar Highland dress was the fossil relic of the universal dress of the Middle Ages, which had been replaced throughout the rest of Europe in the $16^{\text {th }}$ century but which had survived, debased indeed but still recognizable" (1983:36).

\section{The Media Framing Theory}

Framing theory, according to McQuail (2005:555), is a philosophical postulation that explains the way in which news content is typically shaped and contextualised by journalists. Framing is the way the news is framed by journalist and how the audience frames news activate certain inferences, ideas, judgements and contrast concerned issues, policies and politicians. The framing theory is closely related to the agenda setting theory but expand the research by focusing on the essence of the issues at hand rather than on a particular issue. According to masscommtheory.com, framing theory suggests that how something is presented to the audience (called the frame) influences the choices people make about how to process that information. Frames are 
abstractions that work to organise or structure message meaning. The most common use of frames is in terms of the frame the news or media place on the information they convey, they are thought to influence the perception of the news by the audience, in this way, it could be seen as a form of second level agenda setting - they not only tell the audience what to think about (agenda setting - theory), but also how to think about that issue (second level agenda setting, framing theory) (http://masscommtheory.com/theoryoverviews/framing-theory/).

Goffman states that there are two distinctions within primary frameworks: natural and social both play the role of helping individuals interpret information so that their experiences can be understood in a wider social context.

Framing implies that the media consciously as gatekeepers organise and present ideas, events and topics they cover. Framing is the way a communication source defines and constructs any piece of information that may have capacity to infuence the audience members interpret the message. Such constructs exists in films where producers and directors use both primary and secondary frames to present psycho-social messages to the audience who may largely be unsuspecting. Films are watched by audiences majorly as a form of entertainment showing that they come to the setting without a critical mind yet it must not forgotten quickly that the selectivity factors in perception are mediating variables between the media and the audience as well as the obstinate audience dimension of the Uses and Gratifications theory where the audience brings their negotiating skills to every communication situation.

\section{The Gatekeeping Theory}

The term gatekeeping was first coined in 1951 by Kurt Lewin to describe those individuals who control food channels and use within groups during the World War 1 and later to describe those who control the transmission of media fare generally. (Folarin: 2005:121). McQuail (2010) describes it as the process by which selections are made in media work especially decision on when or not to allow a particular news report to pass through the gates of a news medium into the news channel. Gatekeeping applies to decisions about distribution and making of existing media products like films. It refers to the power to give or withhold access to different voices in the society.

A gate keeper is any person or formally organised group directly involved in relaying or transferring information from one individual to another through a mass medium. This could be a reporter, a journalist, a film producer, a script writer, a film director, a network censor, a newspaper executive or any individual in the processing or controlling of messages disseminated through mass media. The three major functions of gatekeepers are 
1. To limit the information received by editing this information before it is disseminated.

2. To expand the amount of information received by giving additional facts or views and

3. To reorganise or interpret the information.

In terms of this study, we see film producers and directors deliberately decide through editing what the audience must see and in what ways they can see what they see such that the presentation is solely seen in order and angle the crew and cast makes it available to the audience. The script writer, costumier, lighting people and so on are involved here in the media system while the audience negotiates perspectives. Camera angles, lighting and effects, the set, audio and effects among many others are tools in the hands of the master crafts in deciding what people see and how they see what they see. As a matter of fact content analysis is an attempt to dissect media offerings in order to ascertain and predict some consistency in the work of gatekeepers. The two theories together call attention significantly to media contents or offerings as the tool in the hands of media operators who must also be weary of media bystanders or audience or spectators or consumers of unyielding individuals with private needs, goals and aspirations as motivations for media attendance or use in some form of negotiations.

\section{Methods}

Theorizing with Gatekeeping and Framing Analysis, this study adopts a content analysis design which is the study of recorded human communications, an objective and systematic analysis of the contents of any document that are manifest. It is often used to investigate the level of presence of a given content in mass communication. The population of this study is limited to 30 movies from the nominated Nollywood movies in the yearly staged Africa Movie Academy Awards (AMAA), from the year 2005-2015 through a systematic sampling with a random start. Content categories include genre of film, type of symbol, setting of symbol, purpose of symbol, cultural implication of symbol, positioning of symbol, symbiotic relations, prominence, and direction of presentation among others.

The Following is the list of all the Nigeria Movies Nominated for the Yearly Staged (AMAA, 2005-2015)

1 Aziza 2 Yesterday 3 The Map 4 Master Mind 5 Ori 6 Eyes Of Gods 7 DabiDabi 8 Dangerous Twins 9 Afonja 10 Games Women Play 11. Anini 12 Abuja Connection 13 Egg Of Life 14 Eagles Bride 15 Osofia In London16 Behind The Closed Doors 17Irapada18 Dearest 19 Widows Cotday Of Atonement 20 Secret Adventure21 Mama 22Mfana Mbagha23 Agbara 24 Oderest 25Rising Moon27 Izza 28 Iwalewa 29 Amazing Grace 3031 Abeni 
32Family Battle 33Sitanda 34 Azima 35 Snake Girl 36 Explosion 37 Maroko 38 Dancing Heart 39 Iranse Aje 40 New Jerusalm 41 Ipa 42 Onitemi 43 African Soldier 44 Hafsah 45 Across the Niger 47 Mission to Nowhere 48 Run Baby Run 49 Check Point 50 Divizion of Division 51 White Water 52 Mirror of Beauty 53 Magical Blessing 54 Kingswill 55 Bleeding Rose 56Ase N Tedunare 57 Per Second Killer 58 Malcom's Echo 59 Shit On The Rock 60 The Lunatic61 Cindy's Note 62 Small Boy 63 Five Apostles 64 Agony of The Christ 65Modupe Temi66 Live To Remember67 The Assassin 68Revolution 69 Smoke And Mirrors 70 Apaadi71 Jenifa 72 Arugba 73 Beautiful Soul 74 State Of One Heart 75 Freedom In Chains76The Tenant 77 Figurine 78 Nnenda 79 Sin Of A Soul 80 Champion of Our Time 81Adventure Of Alayo82 Silent Scandal 83 Jungle Rode 84 Lilies Of The Ghetto 85 High Blood Preasure86 The Camera 86 Sura La 870mo Iya Kan 88Prince's Bride 89 Perfect Picture 90 Fulani91 I Sing Of A Well 92 A Sting In A Tale 93 Guilty Pleasure94 No Jersy No Match 95The Mirror Boy96 Anchor Baby 97 In America: The Story Of The Soul Sister 98 Aramotu 99 Yemoja 100A Private Storm101 Duty102 6 Hours To Christmass 103 Elimina 104 Tango With Me 105 Adesuwa 106 Inale 107 Man On Ground 108 There Is Nothing Wrong With My Uncle 109 The Young Smoker 110Queen's Desire111Unwanted Guest 112 Phone Swap 113 Who Owns Da City114 Behind The Mask 115 Braids On A Bald Head116 Alero's Sister 117Oba 118 Two Brides \& A Baby 119 Shattered 120 Mr \& Mrs121 Zr-7 122Blood \& Hena 123 Damage124 Bank Job 125 Family On Fire 126 Confusion Na Wa 127 Heroes \& Zeroes 128 Hoodrush 129 B For Boy 130 Apaye131Accident132 Aisha's Story 133 The Legacies Of Rubbies 134 The Supreme Price 135 Gone Too Far136Cheetanah137 Affairs Of The Heart 138 Stigma139 Dazzling Mirage 140 Invasion 1897141 A Place In The Stars 142 Iyore143 30 Days In Atlanta144 Iya Alalake 145 October 1146 While You Slept.

In view of the comprehensive list of Nollywood movies nominated for AMAA from the year 2005-2015, the Kth element in the frame was selected, where $\mathrm{K}$, the sampling interval was calculated as $\mathrm{K}=\mathrm{N} / \mathrm{n}$ where, $\mathrm{N}$ is the population size and $\mathrm{n}$ is the sample size. The total population of study was 146 movies of which 30 were sampled. Therefore $K=146 / 30=4.8$. Therefore, every $5^{\text {th }}$ movie, starting from the first movie on the table was selected as the sample to be examined for purpose of this study. 
The Following is the List, Nomination Year and Duration of the Randomly Selected Nigerian Movies for the Purpose of the Study;

\begin{tabular}{|c|c|c|}
\hline Movie Title & Nomination Year & Movie Duration \\
\hline Aziza & 2005 & $01: 44: 30$ \\
\hline Ori & 2005 & $01: 53: 13$ \\
\hline Games Women Play & 2005 & $00: 57: 30$ \\
\hline Osofia in London & 2005 & $01: 24: 18$ \\
\hline Secret Adventure & 2006 & $01: 22: 27$ \\
\hline Rising Moon & 2006 & 02:06:27 \\
\hline Apesin & 2007 & 01:59:47 \\
\hline The Snake Girl & 2007 & $01: 24: 33$ \\
\hline New Jerusalem & 2008 & $01: 46: 47$ \\
\hline Across the Niger & 2008 & $01: 15: 56$ \\
\hline Onitemi & 2008 & 01:04:31 \\
\hline Bleeding Rose & 2008 & $01: 23: 12$ \\
\hline The Lunatic & 2008 & 01:41:39 \\
\hline Modupe Temi & 2009 & 01:32:00 \\
\hline Apaadi & 2009 & $01: 46: 41$ \\
\hline Freedom in Chains & 2010 & $01: 54: 16$ \\
\hline Champion of our time & 2010 & $01: 52: 32$ \\
\hline High Blood Pressure & 2010 & $01: 10: 38$ \\
\hline Fulani & 2010 & 01:01:41 \\
\hline The Mirror Boy & 2011 & $01: 27: 16$ \\
\hline A Private Storm & 2011 & 01:08:02 \\
\hline Adesuwa & 2012 & 01:07:41 \\
\hline Queen's Desire & 2012 & 01:02:38 \\
\hline Braids on a Bald Head & 2012 & $00: 24: 52$ \\
\hline Mr \& Mrs & 2012 & $01: 39: 40$ \\
\hline Family on Fire & 2012 & $00: 43: 43$ \\
\hline Apaye & 2014 & $00: 35: 29$ \\
\hline Iya Alalake & 2015 & $01: 13: 50$ \\
\hline Invasion 1897 & 2015 & 01:53:01 \\
\hline Oct-01 & 2015 & $02: 25: 16$ \\
\hline 30 movies & 10 years & 43:04:06 \\
\hline
\end{tabular}




\section{Data Presentation}

Fig 1: Count of Movie Title by Nomination Year

6

5

4

3

2

1

0

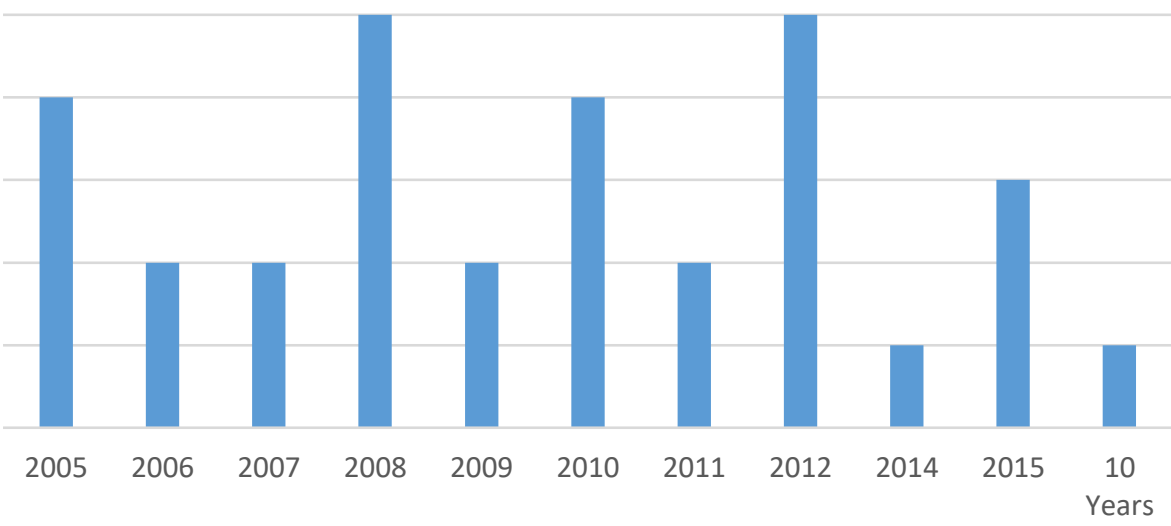

The above figure showed that 5 movies were selected in the year (2008 and 2012), 4 movies were selected in the year (2005 and 2010), 3 movies were selected in the year (2015), 2 movies were selected in the year (2006, 2007, 2009, and 2011), and 1 movie was selected in the year 2014). This amounts to 30 films selected randomly within the interval of 10 years.

Table 2: Genres of the selected Movies

\begin{tabular}{|c|c|c|}
\hline & Value & $\%$ \\
\hline Tragedy & 12 & $40 \%$ \\
\hline Comedy & 4 & $13 \%$ \\
\hline Tragicomedy & 14 & $47 \%$ \\
\hline Total & 30 & $100 \%$ \\
\hline
\end{tabular}

Table 2 shows that $47 \%$ of the selected movies were tragicomedy, $40 \%$ are tragedy while $13 \%$ are comedy.

Table 3: Settings of the Selected Movie

\begin{tabular}{|c|c|c|}
\hline Settings of the Selected Movies & Value & $\%$ \\
\hline Rural & 9 & $30 \%$ \\
\hline Urban & 12 & $40 \%$ \\
\hline Rural Urban & 9 & $30 \%$ \\
\hline Total & 30 & $100 \%$ \\
\hline
\end{tabular}

Table 3 shows that $40 \%$ of the presented Nigeria national symbols in selected Nigeria movies are in the urban setting, 30\% are presented in the rural setting while $30 \%$ are presented in the rural-urban setting. 
Table 4: Rate of Nigerian Movies Presenting Nigeria national symbols contents

\begin{tabular}{|c|c|c|}
\hline & Value & $\%$ \\
\hline Movies with Nigeria national symbols & 9 & $30 \%$ \\
\hline Movies with no presentation of national symbol & 21 & $70 \%$ \\
\hline Total & 30 & $100 \%$ \\
\hline
\end{tabular}

Table 4 shows that $70 \%$ of the selected Nigeria movies did not present any of the Nigeria national symbols while $30 \%$ of the movies presented Nigeria national symbol.

Table 5: Prevalent Level of National Symbols Presented in all of the Selected Movies

\begin{tabular}{|c|c|c|}
\hline Nigeria National Symbols & Value & $\%$ \\
\hline The Nigeria National Flag & 2 & $7 \%$ \\
\hline The Nigeria National Coat of Arm & 1 & $3 \%$ \\
\hline The Nigeria National Anthem & 1 & $3 \%$ \\
\hline The Nigeria National Currency & 6 & $20 \%$ \\
\hline The Seal of the President of the Federal Republic of Nigeria & 0 & $0 \%$ \\
\hline Total & 10 & $33 \%$ \\
\hline
\end{tabular}

Table 5 shows that there are total of $33 \%$ prevalence level of the Nigeria national symbols presented in all of the selected movies.

Fig 2: The National Symbol with the Highest Prevalence Level

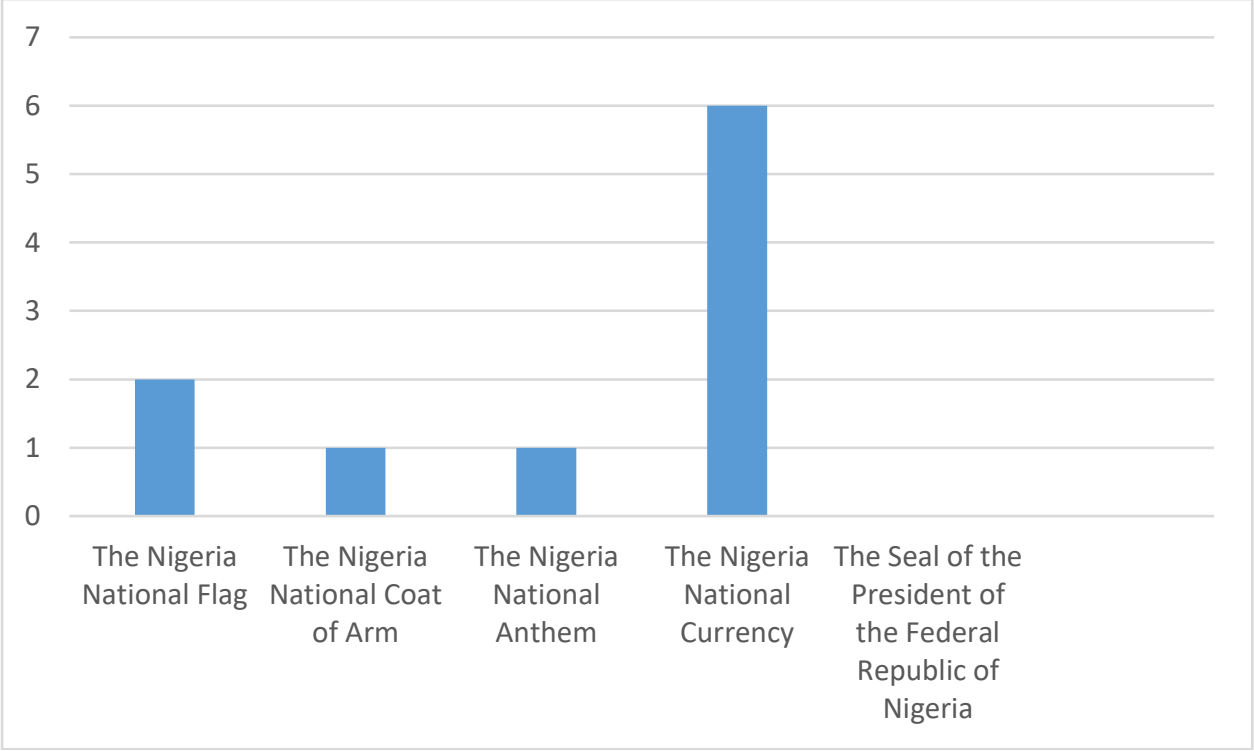

The above figure shows that the Nigeria national currency have the highest prevalence level in the selected Nigeria Movies, followed by the Nigeria national Flag, the Nigeria Coat of arm, the Nigeria national anthem while the seal of the president was not presented in any of all the selected Nigerian movies. 
Table 6: Categories of People Involved in National Symbols

\begin{tabular}{|c|c|c|}
\hline Categories of People Involved in National Symbol & value & $\%$ \\
\hline Adult alone & 3 & $10 \%$ \\
\hline Youth alone & 0 & $0 \%$ \\
\hline Children alone & 0 & $0 \%$ \\
\hline Mixture of adult, youth and children & 4 & $13 \%$ \\
\hline None of the categories of people & 3 & $10 \%$ \\
\hline Total & 10 & $33 \%$ \\
\hline
\end{tabular}

Table 6 shows that $13 \%$ of the people involved in the presentation of Nigeria national symbols in the selected Nigerian movies are a mixture of adult, youth and children, $10 \%$ involved just the adult while $10 \%$ do not involve any categories of people.

Table 7: Duration of Symbol Presentation

\begin{tabular}{|c|c|c|}
\hline & Value & $\%$ \\
\hline $1-20$ secs & 8 & $27 \%$ \\
\hline $21-40$ secs & 0 & $0 \%$ \\
\hline $41-60$ secs & 0 & $0 \%$ \\
\hline 1 mins and above & 2 & $6 \%$ \\
\hline Total & 10 & $33 \%$ \\
\hline
\end{tabular}

Table 7 shows that $27 \%$ of the Nigeria national symbols are presented in a fleeting seconds while $6 \%$ of the symbols are presented above 1 minute.

Table 8: Settings of the Presented Nigeria National Symbols in the Selected Nigerian

Movies

\begin{tabular}{|c|c|c|}
\hline & Value & $\%$ \\
\hline Public Office & 2 & $7 \%$ \\
\hline Private Office & 1 & $3 \%$ \\
\hline Institution of Learning & 2 & $7 \%$ \\
\hline Leisure Place & 2 & $7 \%$ \\
\hline Home & 1 & $3 \%$ \\
\hline Outdoor & 2 & $7 \%$ \\
\hline Total & 10 & $33 \%$ \\
\hline
\end{tabular}

Table 8 shows that $7 \%$ of the Nigeria national symbols were presented in Public offices, 7\% were presented in institution of learning, 7\% at leisure places, $7 \%$ were presented outdoor, $3 \%$ were presented in private offices and $3 \%$ were presented at homes.

Table 9: Light in which the National Symbols were presented in the Selected Movies

\begin{tabular}{|c|c|c|}
\hline & Value & $\%$ \\
\hline Favourable & 2 & $6 \%$ \\
\hline Not favourable & 0 & $0 \%$ \\
\hline Neutral & 8 & $27 \%$ \\
\hline Total & 10 & $33 \%$ \\
\hline
\end{tabular}


Table 9 shows that $27 \%$ of the Nigerian movies presented the Nigeria national symbols from the neutral perspective while $6 \%$ of the selected movies presented them from favourable perspective.

\section{Findings of the study}

- $\quad$ The study reveals that Nigeria national symbols were not presented in most of Nigerian movies.

- $\quad$ The study shows that Nigeria national symbols were featured scantily or presented to a very low extent in Nigerian films.

- $\quad$ The study shows that national currency is the most prevalent Nigeria national symbols presented in Nigeria movies.

- The study shows that youth and children are not involved in the exhibition of Nigeria national symbols without the aid of adults.

- $\quad$ The study reveals that presentation of Nigeria national symbols at home and private offices was low.

- The study shows that attention was not paid to the presentation of the Nigeria national symbols as they were often exhibited in fleeting seconds.

- $\quad$ The study reveals that there were often non deliberate attempt in presenting the Nigeria national symbols in Nigeria movies.

- The study shows low, scanty and none deliberate presentation of national symbols as well as $27 \%$ neutral depictions implying that the Nigerian State is not projected vividly through symbols.

\section{Discussion of Findings}

Notwithstanding the fact that films in this study were nominated for awards, they still have tendentious presentation of filmic and dramatic offerings more than image branding stimuli or corporate identity presentation. The finding that national symbols were not featured in most Nigerian films corroborate the call by Alawode (2007) for a reorientation of filmmakers in the country for awareness of the wares as sales point for the nation within and without its shores. Likewise the scanty presentations of national symbols support (Elgenius 2005; Bornman 2005) that national symbols are important landmarks in nation building, national identities, and expressions of nationhood while other studies (Alawode \& Uduakobong 2014; Alawode 2005/2006; Alawode 2007; Alawode \& Sunday 2013) support the scanty and near absence of national symbols in Nigerian films. The findings of minimally low features in both private and public worlds, presented in fleeting seconds as accidental non-deliberate features with neutral or unreadable meaning points to the perspective that Nigerian films follow filmic and dramatic lines exclusively and could not serve the purpose of corporate national image 
selling or tourism promotion while also confirming the perspective in misrepresentations, overrepresentations and underrepresentation.

Every nation has a history, antecedents, heroes, travails, victories or accomplishments, notable places, events, activities and occurrences among others, and like Elgenius (2005) points out, they all contribute to expressions of nationhood as integral part of identity-making, maintenance and change. This is equally similar to the Highland tradition of Scotland enumerated earlier with historical events, acts of Parliament, individuals, books among others. Tendencies to miss out on them in Nigerian films does not indicate their absence in the cultural milieu or as secular religion of the nation but that as a young growing nation and newly evolving film industry (less than three decades compared to more than ten decades Hollywood and even older European film industries), deliberate efforts are needed to nurture the young industry to maturity through collaborative efforts to offer evidences indicating that national symbols express deeper aspects of meanings of a nation and function as integrative and or divisive forces, form a central part of a 'secular religion' which provides anchorage in a dynamic world and raise collective consciousness of community identity in self identification and community history. Conclusively, national symbols will only serve as commemorative emblems when they are integrated in our entertainment fares such that they raise our consciousness even as communication stimuli to look backwards, understand the present and project into the future. However, there are specific film offerings devoting attention to national history and antecedents such as October 1 commemorating the independence anniversary of the Nigerian nation on October 1, 1960 from the British Government. Films like this did not get in the selected films because the selection was done using scientific sampling. Future studies can concentrate on such films through purposive sampling selection.

\section{References:}

1. Alawode S.O. (2005/2006) Home video portrayal of the Nigerian Environment: A content Analysis- The Nigerian Journal of Communications Vol. 4 Numbers $1 \& 2$ pp77-91.

2. Alawode S.O. (2007) Nigerian environment in the eye of Nigerian home videos Journal of Communication \& Language Arts Vol.2 pp62-81

3. Alawode S.O \& Sunday U (2013) Showcasing Nigeria through the home videos IOSR Journal ofHumanities and Social Science (IOSRJHSS) Vol.13 Issue1 July-Aug. pp25-33

4. Alawode S.O and Uduakobong Sunday (2014)The Reality of Nigeria image from the perspective of the home videos Journalism and Mass Communication March 2014 Vol. 4 No 3, 180-196. 
5. Bornman, Elirea (2005) National symbols and national building in the post apartheid south Africa. Department of Communication Science, University of South Africa P.O Box 392, UNISA 003, South Africa. Published online 2 November. 2005.

6. CIA - The World Fact book 2002. "Nigeria" online available: <http://www.cia.gov/cia/publications/factbook/geos/ni.html>

7. David A. Butz (2009). 'National symbols as Agent of Psychological and Social Change' Political Psychology, Vol. 30, No. 5, 2009.

8. Elgenius, Gabriella (2005) Expression of Nationhood: National symbols and ceremonies in Contemporary Europe Unpublished Phd Thesis to London School of Economics and Political Sciences. University of London, http://core.ac.uk/download/files/170/16390523. pdf. 370 pages. Retrieved 26/6/16

9. Encyclopædia Britannica. "Nigeria" online available: <http://search.eb.com/eb/article?eu=120185>

10. Flag, Motto, Pledge and Coat-Of-Arms. Online available: http://naijapositive.myfastforum.org

11. Folarin, B (2005) Theories of Mass Communication; An Introductory Text, Bakinfol Publications Ibadan.

12. Framing Theory (http://masscommtheory.com/theoryoverviews/framing-theory/

13. Gabriel Faniyan, (2103). 'A Stylistic Analysis of the Nigerian National Anthem and Pledge' Online available: https://gabrielfaniyan.wordpress.com/2012/08/07/a-stylistic-analysisof-the-nigerian-national-anthem-and-pledge/ retrieved at $2.30 \mathrm{pm}$ 15/3/2016

14. Goffman, E (1974) in framing theory retrieved from http://masscommtheory.com/2015/12/02/framingtheory

15. Ivan Sachein Bruce Berry (2015) Online available: http://www.crwflags.com/fotw/flags/ng.htm

16. McQuail (2010) McQuail's Mass Communication Theory, $6^{\text {th }}$ edition London: Sage Publications Ltd

17. Stock, Robert. "Nigeria." Microsoft® Encarta ${ }^{\circledR} 2009$ [DVD]. Redmond, WA: Microsoft Corporation, 2008. http://www.123independenceday.com/nigeria/national-anthem.html

18. The Nigeria Coat-of-Arms: 'Everything you need to know about it'. Online available: http://nigerianfinder.com/nigeria-coat-of-arm-armsnigerian-coat-of-arms/

19. 'The People of Nigeria, Ethnicity' online available: http://www.countriesquest.com/africa/nigeria/the_people_of_nigeria/ ethnicity.htm 
20. Trevor-Roper, Hugh (1983) The Invention of Tradition: The Highland Tradition of Scotland In Hobsbawm, Eric \& Ranger, Terence (Eds.) The Invention of Tradition. Cambridge; Cambridge University Press. Pages 15-41 